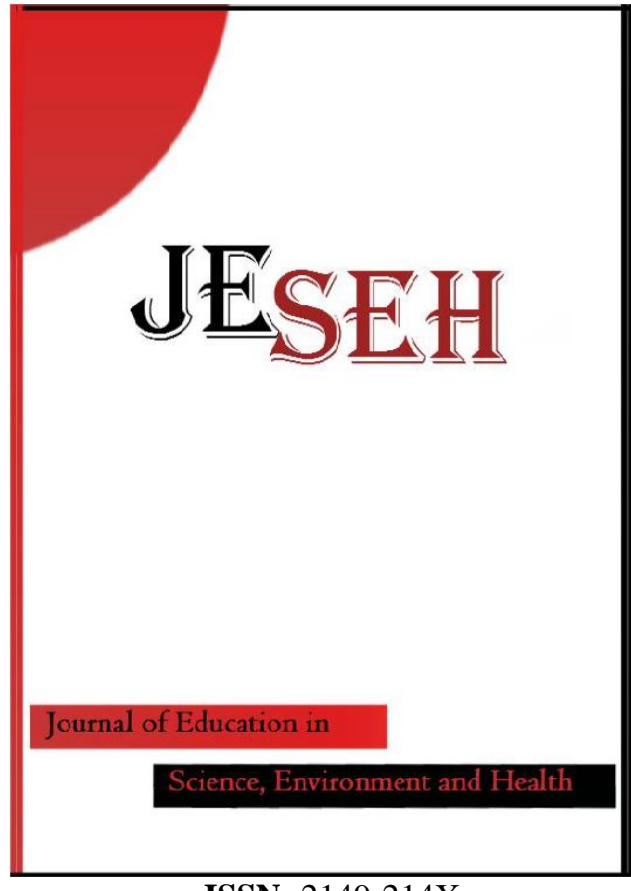

ISSN: $2149-214 \mathrm{X}$

\section{Journal of Education in Science,} Environment and Health

www.jeseh.net

Preservice Teachers' Perception Levels Concerning Consumer Environmental Consciousness

Yurdal Dikmenli

Ahi Evran University

To cite this article:

Dikmenli, Y. (2017). Preservice teachers' perception levels concerning consumer environmental consciousness. Journal of Education in Science, Environment and Health (JESEH), 3(2), 157-164. DOI:10.21891/jeseh.326741

This article may be used for research, teaching, and private study purposes.

Any substantial or systematic reproduction, redistribution, reselling, loan, sub-licensing, systematic supply, or distribution in any form to anyone is expressly forbidden.

Authors alone are responsible for the contents of their articles. The journal owns the copyright of the articles.

The publisher shall not be liable for any loss, actions, claims, proceedings, demand, or costs or damages whatsoever or howsoever caused arising directly or indirectly in connection with or arising out of the use of the research material. 


\title{
Preservice Teachers' Perception Levels Concerning Consumer Environmental Consciousness
}

\author{
Yurdal Dikmenli
}

\begin{tabular}{|c|c|}
\hline Arti & Abstract \\
\hline History & \multirow{13}{*}{$\begin{array}{l}\text { People who strive to prevent harm to the environment while utilizing it and to } \\
\text { maintain a livable environment is related to educational and cultural values. If } \\
\text { we want the next generation to live in an environment as undisturbed as we live } \\
\text { in now, environmentally friendly products should be consumed and waste should } \\
\text { be prevented. Thus, raising an environmental consciousness among consumers is } \\
\text { of vital importance. Environmental consciousness is shaped by individuals' } \\
\text { knowledge, attitudes, sensitivity and beneficial behavior towards environment. } \\
\text { In this sense, the primary aim of this study is to determine preservice teachers' } \\
\text { perception levels of consumer environmental consciousness in terms of different } \\
\text { variables. The sample of the study consists of } 396 \text { preservice teachers from } \\
\text { various departments in the Faculty of Education in Ahi Evran University } \\
\text { between the } 2015-2016 \text { academic years. } 70.2 \% \text { of the sample is female while } \\
29.8 \% \text { is male. The Consumer Environment Consciousness Scale (CESS) which } \\
\text { was developed by the researcher, and contains } 28 \text { items, } 20 \text { of which are positive } \\
\text { and } 8 \text { of which are negative, was used for data collection. The gathered data was } \\
\text { analyzed using SPSS } 17 \text { software. The study findings suggest that the participant } \\
\text { preservice teachers have a medium level of consumer environment } \\
\text { consciousness and this consciousness differs significantly in terms of gender, } \\
\text { income level and whether or not they have had environment lessons before. } \\
\text { Additionally, there was found to be no meaningful difference in perception } \\
\text { levels in terms of residential area the participants live in. }\end{array}$} \\
\hline $\begin{array}{l}\text { Received: } \\
23 \text { November } 2016\end{array}$ & \\
\hline $\begin{array}{l}\text { Acce } \\
14 \mathrm{~N}\end{array}$ & \\
\hline Keywords & \\
\hline Geog & \\
\hline & \\
\hline ss & \\
\hline & \\
\hline & \\
\hline & \\
\hline & \\
\hline & \\
\hline & \\
\hline
\end{tabular}

\section{Introduction}

Environment is defined as the place in which living and non-living things coexist, including both natural and manmade elements in constant change and transformation, and is of an interacting nature. In this interacting process, the dominant role belongs to humans. Humans have the desire and skills to change the environment for living and non-living creatures for their own sake, and have historically tried to fulfill their desires without considering the future (Yücel, Uslu, Altunkasa, Güçray and Say, 2008).

Although nature has the ability to renew itself, this ability is limited. Since humans started to live on Earth, the relationship between nature and humans has been based on humans' utilizing natural sources. With the development of science, humans have dominated nature (Türküm, 1998). Humans have utilized nature insensibly, which in turn has become a major environmental issue of today and a threat for all living creatures (Seçkin, Yalvaç and Çetin, 2010). Therefore, the environment has become a problem which needs to be dealt with both on a national and international level. That humans learn to live in harmony with nature and to prevent any disturbance of ecological balance are of great importance to maintain humanity (Kahyaoğlu, Daban and Yangin, 2008).

Education is the most influential way to overcome the problems society faces or will face and to construct the future (Hoody 1995). Environmental education addresses individuals' cognitive, affective and kinetic learning fields. It is the process of developing attitudes, norms, knowledge and skills. It is also the process of cultivating their results (Erten, 2004). Environmental education is a lifelong issue surrounding the whole society and producing vital long term results (Kaya and Gündoğdu, 2007). The significance, necessity and effects of environmental education, and the inadequate training about environmental consciousness for students at schools has recently become a heavily discussed topic at many schools around the world (Aydın, Coşkun, Kaya and Erdönmez, 2011; Bonnett and Williams, 1998; Cheng and Monroe, 2010; Meydan and Doğu, 2008; Tahiroğlu and Çetin, 2013). The general outcomes of researches related to environmental education suggest that 
environmental consciousness, knowledge and sensibility rise when education is delivered at an early age with visual, audio and practical methods (Tahiroğlu, Yıldırım and Çetin, 2010).

Geography plays a special part in environmental education as its content is the interactions between humans and the environment. Since geography interacts with both natural and social sciences, it has advantages to deal with environmental problems in an objective and integrative perspective (Arslan, 2009). Also, values education at schools aiming to develop environmental consciousness has positive effects on raising awareness among students (Tahiroğlu, Yıldırım, and Çetin, 2010). If an individual does not try to decrease waste, does not save energy and water, does not prefer buying recyclable products, does not regularly check the potential harms of a product he buys, does not actively protect the environment and keeps his silence when he sees somebody polluting the environment, he cannot be said to have environmental consciousness. Additionally, there is no meaning in what these people know about the environment (Erten, 2004). In this sense, environmental consciousness can be defined as developing sensitivity towards the environment among individuals for a sustainable life.

As environmental consciousness and education involve lifelong knowledge, attitudes, behaviours and skills, teaching programs which focus on an intense interaction with the environment should be designed and practiced (Bonnett and Williams, 2006). According to international studies concerning environmental education, the optimal education level for delivering environmental education is secondary education, and teachers play critical roles in attaining the goals of environmental education. Thus, secondary education teachers should be trained so that they can deliver environmental education and consciousness (IEEP, 1994; Ünal and Dımışk1, 1998).

In recent years in Turkey, it has been observed that the number of consumers with environmental consciousness and concerns has risen, and the consumption of environmentally friendly products has reflected this increase in consciousness (Çabuk and Nakıboğlu, 2003). Since the 1980s, environmental consciousness and concern has increased among consumers, which results in them demonstrating environmentalist behaviours in their buying decisions, during and after the consumption process. However, the number of environmental disasters occurring with human's effects has increased despite all those things. So, it is a must that consumers develop more environmental and consumption consciousness (Horton, 2003).

As geography focuses on the interaction between human and environment, it dwells on environmental issues. For this reason, it is aimed that the students learn the ecology and environmental issues in the field of environmental and community learning within the Geography Course Curriculum and gain attitudes and values in this subject. The knowledge, skill and attitude of mankind are very important in determining the mutual interaction with the environment. For this reason, all individuals have to be aware of the impacts and effects on the environment. It is also the responsibility of the geography educators to equip society with values and attitudes, such as to equip them with "ethical values" that will guide them in carrying out their vital activities and to make them aware of the environment (Artvinli, 2007).

In a review of the literature, a number of studies about consumer environmental consciousness have been found, but the number of these studies in the field of geography are quite low, and studies conducted in other fields have their own field limitations (Yeniçeri, 2009; Aracıŏlu and Tatlıdil, 2009; Köse and Gül, 2014). Additionally, these studies were observed to be limited to the fields of marketing, in terms of the consumer dimension, and science education, in terms of the environmental consciousness dimension. However, in Geography Course Teaching Program (MEB, 2015) environmental consciousness is adopted as an essential principle, and protecting the environment is determined to be of geographic merit, which makes this study to be of more importance for the field of geography. This study aims to measure consumer environmental consciousness levels of preservice teachers, and it is believed that this study would highly contribute to the geography field.

\section{Method}

This study is an ex-post facto study which means not controlling the variables and investigating the phenomena after it had occurred. The demographic background form and the CESS were administered to voluntary preservice teachers in the spring semester of the 2015-2016 academic year. The study aims to analyze preservice teachers' consumer environmental consciousness, and demographic factors' influence on it. The dependent variable was consumer environmental consciousness. The independent variables were gender, settlement, SES, and attending a course relating to the environment. 


\section{Sample}

The convenience sampling method was used in this study. Convenience sampling refers to a group of individuals who are available for the study (Fraenkel and Wallen, 2012). The sample consisted of 642 preservice teachers. The data was collected in the 2015-2016 Spring semester at the Faculty of Education, Ahi Evran University. Demographic background information of the sample is summarized in Table 1.

Table 1. Demographic characteristics of the sample $(\mathrm{n}=642)$

\begin{tabular}{|c|c|c|c|c|c|}
\hline \multicolumn{2}{|l|}{ Gender } & \multicolumn{2}{|c|}{ Attending A Course } & \multicolumn{2}{|c|}{ Settlement } \\
\hline Male & $23.1 \%$ & Yes & $58.9 \%$ & Rural & $17.6 \%$ \\
\hline Female & $76.9 \%$ & No & $41.1 \%$ & Urban & $82.4 \%$ \\
\hline \multicolumn{2}{|l|}{ Ranking } & \multicolumn{2}{|c|}{ Socio-economic Status } & & \\
\hline Freshman & $26.6 \%$ & Low & $19.9 \%$ & & \\
\hline Sophomore & $26.8 \%$ & Middle & $65.1 \%$ & & \\
\hline Junior & $23.5 \%$ & High & $15 \%$ & & \\
\hline Senior & $23.1 \%$ & & & & \\
\hline
\end{tabular}

As seen above, nearly one-fourth of the sample was male, and the rest were female. More than half of the sample had a middle socio-economic status (SES) background. 82.4\% of preservice teachers were from urban areas of Turkey, and $17.6 \%$ were from rural areas. Rankings of preservice teachers were approximately equally divided. Furthermore, more than half of the preservice teachers had attended a course concerning the environment.

\section{Data Collection and Analysis}

A demographic background form was used to collect information about gender, settlement, SES, and rankings of preservice teachers. Whether preservice teachers had attended a course relating the environment was also asked, The Consumer Environment Consciousness Scale (Dikmenli and Konca, 2016) was used to investigate preservice teachers' environmental consciousness. The Consumer Environment Consciousness Scale (CESS) is a five point scale and consists of 28 items ( 8 items are negative, and 20 items are positive). The items are divided under four factors; Susceptible Consciousness (10 items), Behavioral Consciousness (9 items), Social Pressure (5 items), and Bias (4 items). The Cronbach's alpha coefficients of the sub-scales was calculated as $.767, .823, .779$, and .753 , respectively. For the current study, the Cronbach's alpha coefficients of the subscales were found to be $.777, .815, .769$, and .756, respectively. To interpret the scores obtained from the scale, the range of the scale was divided by three, and the scores are categorized as low (1.00-2.33), middle (2.343.66), and high (3.67-5.00).

Frequency, percentage, mean, standard deviation, and multiple regression analysis were used in data analysis process. Demographic characteristics of the sample were descriptively analyzed by using frequency and percentage. Multiple regression analysis was conducted to investigate the relationship between the independent variables, and the dependent variable. Before conducting multiple regression analysis, the assumptions (Tabachnick and Fidell, 2007) were checked. It was seen that the assumptions were met, so the analysis was done.

\section{Results}

Table 2 presents a descriptive summary of preservice teachers' scores obtained from the CESS and sub-scales. As seen in the table, on a five-point scale, preservice teachers appear to have high levels of consumer environmental consciousness. When the minimum and the maximum scores are analyzed, it can be seen that scores of preservice teachers were spread from minimum points of sub-scales to maximum points. While preservice teachers had the highest mean score on susceptible consciousness, they had the lowest mean score on bias. While the mean score of susceptible consciousness sub-scale represents a high level of consciousness, the other three sub-scales and total score of the CESS point middle level of consciousness.

When the attitudes of preschool teachers towards technological tool and material use participating to the research were examined on the basis of sample, the mean was 4.21 which refers to high attitude. Additionally, $\% 90.26$ of 
teachers have a high attitude and $\% 8.74$ of teachers have a moderate attitude. In the light of these findings, it can be concluded that preschool teachers have quite a positive attitude towards technological tool and material use.

Table 2. Description of preservice teachers' scores obtained from the CESS

\begin{tabular}{ccccc}
\hline & Min & Max & Mean & Std. Dev. \\
\hline Susceptible Consciousness & 1.60 & 5.00 & 3.72 & 0.55 \\
\hline Behavioral Consciousness & 1.00 & 5.00 & 3.23 & 0.68 \\
\hline Social Pressure & 1.40 & 4.80 & 3.11 & 0.59 \\
\hline Bias & 1.00 & 5.00 & 3.09 & 0.74 \\
\hline Total & 2.07 & 4.46 & 3.36 & 0.41 \\
\hline
\end{tabular}

In order to examine how well gender, settlement, SES, and attending a course relating to the environment predicts preservice teachers' environmental consciousness, multiple linear regression analysis was conducted and presented in Table 3. Results of the analysis showed that the linear combination of predictor variables significantly predicted the dependent variable $(R=.332, F=13.90, p<0.05)$.

Table 3. Results of multiple regression analysis between the predictor variables and environmental consciousness

\begin{tabular}{|c|c|c|c|c|c|}
\hline Multiple Regression & Analysis of & ariance & & & \\
\hline$R=.332$ & Source & $d f$ & $S S$ & $M S$ & F-ratio \\
\hline$R^{2}=.1102$ & Regression & 4 & 4556.82 & 1139.206 & \multirow{2}{*}{$8.900^{*}$} \\
\hline S.E. $=11.31379$ & Residual & 636 & 81409.165 & 128.002 & \\
\hline
\end{tabular}

Specifically, preservice teachers' gender, SES, and attending a course relating environment each made a significant contribution to the prediction of preservice teachers' consumer environmental consciousness $(p<.05)$, as seen in the Table 4. However their settlement did not predict their environmental consciousness $(p>.05)$. Table 4 also presents $\mathrm{b}$ values, standard error of $\mathrm{b}$ values, beta values, $\mathrm{t}$ values, and $\mathrm{p}$ values of the constant and the independent variables. It can be seen that the beta values for gender $(B=.082, t=2.118)$, SES $(B=.122$, $t=3.011)$, and attending a course $(B=.163, t=4.162)$ were significantly high. However, the beta values for settlement $(B=.007, t=.187)$ pointed to an insignificant effect of settlement of preservice teachers on their consumer environmental consciousness.

Table 4. The beta values of the predictor variables

\begin{tabular}{llllll}
\hline & B & SEB & Beta & t & p \\
\hline Constant & 94.226 & 1.646 & & 57.256 & .000 \\
\hline Gender & 2.262 & 1.068 & .082 & 2.118 & .035 \\
\hline Settlement & -.228 & 1.217 & .007 & .187 & .851 \\
\hline SES & -1.289 & .428 & .122 & 3.011 & .003 \\
\hline Attending a course & 3.835 & .922 & .163 & 4.162 & .000 \\
\hline \multicolumn{1}{c}{$\mathrm{p}<0.05$} & & & & &
\end{tabular}

\section{Conclusion}

According to study results, preservice teachers have a medium level of consumer environmental conscious. Regarding the sub-scales, they also have medium levels in behavioural consciousness, social pressure and bias. However, they demonstrate a high level of susceptible consciousness. Consumer environment consciousness is the dimension in which environmental knowledge transforms into skill fairly. However, the levels of skill and perception among participant preservice teachers were not high.

Thus, in the framework of Geography Course Teaching Program and Principles (2015), environmental consciousness is adopted; protecting the environment is accepted as a geographic value, and additionally, the statement "Humans have to adopt a lifestyle in harmony with environment" is included in theme Geography's Agent: Human. In this sense, it can be understood that in the last version of the geography teaching program aims to constitute environmental consciousness and knowledge among students through various ways. It was also determined that environmental consciousness does not influence environmentalist behaviours directly, but the those developing environmentalist attitudes also reflect it in their behaviours and buy ecological products 
(Roberts and Bacon, 1997; Yılmaz, Çelik and Yağızer, 2009). In their study with university students, Dono, Webb and Richardson (2009) found significant relationships between environmental attitudes and behaviours. As Straughan and Roberts (1999) claim, although individuals worry about environmental issues, if they do not believe that they cannot contribute to fight against environmental problems, they do not reflect their concerns in their behaviours. Hence, it can be inferred that students are mostly in the level of knowledge and attitude but are not sufficiently on the level of behaviour and competency yet.

The consumer environmental consciousness levels of preservice teachers were found to differ significantly in terms of gender. Some studies (Kahyaoğlu, 2014; Timur and Y1lmaz, 2011) addressed the lack of any effect of gender on environmental consciousness while many other studies revealed that females' consciousness levels towards the environment are higher than males (Torlak, 2001; Ay and Zümrüt, 2005; Alp, Ertepınar, Tekkaya, and Yılmaz, 2006; Dibgy, 2010; Yılmaz and Anderson, 2004; Gökçe, Kaya, Aktay and Özden, 2007; Çabuk, Nakıboğlu and Keleş, 2008; Arabacıŏlu and Tatlıdil, 2009; Yeniçeri, 2009; Yaraş, Akın and Şakacı, 2011, Özgen and Kahyaoğlu, 2013). Considering these researches, it can be concluded that female students are more interested in environmental issues than male students.

The consumer environmental consciousness levels of preservice teachers were found to show no meaningful differences in terms of settlement places. Similarly, in his study Öztürk (2013) revealed no meaningful difference based on settlement place, which indicates that both study findings are in accordance with each other. However, some other researches demonstrated that urban people have more environmental attitudes and consciousness than rural people (Straughan and Robert, 1999; Ek, Kılıç, Öğdüm, Düzgün and Şeker, 2009; Şama, 2003). This study's findings suggest that whether coming from urban or rural does not have any effect on consumer environmental consciousness, which can be explained by the fact that preservice teachers have the same educational levels, because it is believed that in creating environmental consciousness in society, even individual consumption contributes to protecting the environment and maintaining this understanding is only possible with education.

Another finding in this study indicates significant differences between consumer environmental consciousness and family incomes. In related studies, it is observed that the higher income families have, the higher level of consumer environmental consciousness they demonstrate (Soonthonsmai, 2001; Çabuk, Nakıboğlu and Keleş, 2008; Yeniçeri, 2009; Yaraş, Akın and Şakacı, 2011). According to post materialist theory (Abramson and Inglehart, 1995), individuals coming from middle/high income families are more sensitive to environmental issues than low/ high income families. In the light of these results, it can be inferred that as the income increases, consumers would gain economic power to buy more expensive but less environmentally harmful products, which in turn refers to an increase in their environmental consciousness.

Lastly, meaningful differences in preservice teachers' consumer environmental consciousness and whether they have had any lectures about environmental issues before were found. Similar results were obtained from many related researches, too (Kahyaoğlu, 2014; Özden, 2008; Tuncer, Tekkaya, Sungur, Çakiroglu, Ertepinar and Kaplowitz, 2009). Also, educational trainings and projects about the environment were revealed to have a positive effect to cultivate environmental consciousness among preservice teachers (Carroll, 2015; Keleş, Uzun and Varnaci Uzun, 2010). However, some studies showed that although students have had lectures about environmental issues, the participation rate to activities related to environment is low (Sağır, Aslan and Cansaran, 2008). Additionally, many studies also mention inadequate environmental trainings in Turkey (Armağan, 2006; Bozkurt, Akın and Uşak, 2004; Atasoy and Ertürk, 2008; Maskan, Efe, Gönen and Baran, 2006; Sülün and Kozcu, 2005). Considering these findings, it can be generally concluded that having lectures about environment increases environmental consciousness, but just lectures are not enough as they do not always bring environmental consciousness to individuals.

\section{Recommendations}

In order to cultivate customer environmental consciousness with its all dimensions among preservice teachers, lectures related to environment should be added to other departments apart from science, social and classroom teacher trainings departments. In fact, these lectures should be included into the whole educational grades so as to cultivate nature love and environment consciousness even at later ages. Teachers who volunteer to manage this duty are thought to be able to raise individuals with consumer environmental consciousness and environmentally friendly and sensitive. Thus, firstly cultivating environmental consciousness among preservice teachers becomes important. With this aim, cooperation among geography courses and other courses should be established, and provide students with opportunities to practice these abilities, because it is difficult that 
knowledge learnt in vitro can transform into behaviours in real life. Also, families should be absolutely included in this process, and engage in activities together with their children so that they may internalize related knowledge, skill and values given at schools. Thus, it is possible to raise individuals endowed with conceptual knowledge about the environment and consumer environmental consciousness.

\section{Acknowledgements or Notes}

This work was supported by the Ahi Evran University Scientific Research Projects Coordination Unit. Project Number: EGT.A3.16.005

\section{References}

Abramson, P. R. \& Inglehart, R. (1995). Value change in global perspective. Ann Arbor, MI: University Of Michigan Press.

Alp, E., Ertepınar, H., Tekkaya, C. \& Yılmaz, A. (2006). İlköğretim öğrencilerinin çevreye yönelik tutum ve bilgileri üzerine bir çalışma, 7. Ulusal Fen Bilimleri ve Matematik Eğitimi Kongresi. Ankara.

Aracıoğlu, B. \& Tatlıdil, R. (2009).Tüketicilerin satın alma davranışında çevre bilincinin etkileri. Ege Akademik Bakış / Ege Academic Review, 9 (2),435-461

Armağan, F. (2006). İlköğretim 7. ve 8. Sınıf öğrencilerinin çevre eğitimi ile ilgili bilgi düzeyleri. Yayınlanmamış Yüksek Lisans Tezi. Gazi Üniversitesi Eğitim Bilimleri Enstitüsü. Ankara

Artvinli, E. (2007). 2005 Yılı 9. Sınıf coğrafya öğretim programı: Öğretmenler açısından uygulanabilirlik düzeyi. (Yayımlanmamış Doktora tezi) Atatürk Üniversitesi Sosyal Bilimler Enstitüsü Ortaöğretim Sosyal Alanlar Eğitimi Anabilim Dalı. Erzurum.

Aslan, A. (2009). Ortaöğretim coğrafya dersi programındaki çevre konularının analizi. Yayınlanmamış Yüksek Lisans Tezi. Marmara Üniversitesi Eğitim Bilimleri Enstitüsü. İstanbul.

Atasoy, E., \& Ertürk, H. (2008). İlköğretim öğrencilerinin çevresel tutum ve çevre bilgisi üzerine bir alan araştırması. Erzincan Eğitim Fakültesi Dergisi. 10(1),105-122

Ay, C. \& Zümrüt E. (2005). Çevre bilinçli tüketiciler. Akdeniz İIBF Dergisi, 10,238-263.

Aydın, F. Coskun, M. Kaya, H. \& Erdönmez, İ. (2011). Gifted students' attitudes towards environment: A case study from Turkey. African Journal of Agricultural Research, Vol. 6(7),1876-1883.

Bonnett, M. \& Williams, J. (1998). Environmental education and primary children's attitudes towards nature and the environment. Cambridge Journal Of Education. 28(2),159-174.

Bozkurt,O., Akın, B. \& Uşak, M. (2004). İlköğretim 6. 7.ve 8. sınıf öğrencilerinin erozyon hakkındaki ön bilgilerinin ve kavram yanılgılarının tespiti. Gazi üniversitesi Kırşehir Eğitim Fakültesi Dergisi. $5(2), 277-285$.

Carroll, K. N. (2015). Mississippi teachers' environmental awareness and usage of the project learning tree curriculum within traditional classrooms. Mississippi State University Department of Foresty. Mississippi.

Çabuk, S.M.A. \& Nakıpoğlu, B. (2003). Çevreci pazarlama ve tüketicilerin çevreci tutumlarının satın alma davranışlarına etkileri ile ilgili bir uygulama. Çukurova Üniversitesi Sosyal Bilimler Enstitüsü Dergisi, 12(12), 39-54.

Çabuk, S., Nakiboğlu, B., \& Keleş, C. (2008). Tüketicilerin yeşil (ürün) satın alma davranışlarının sosyodemografik değişkenler açısından incelenmesi. Journal Of The Cukurova University Institute Of Social Sciences, 17(1),85-102

Chen-Hsuan Cheng, J., \& Monroe, M. (2010). Connection To Nature: Children's Affective Attitude Toward Nature. Environment and Behavior, 44(1),31-49.

Dibgy B. L. C. (2010). An examination impact of non-formal and informal learning on adult environmental knowledge, attitudes, and behaviors, Unpublished Doctoral Dissertation, University of Minnesota, USA

Dikmenli, Y., \& Konca, A. S. (2016). Validity and reliability study of environmental consciousness scale/Tüketici çevre bilinci algı ölçeği geçerlik ve güvenirlik çalışması. Eğitimde Kuram ve Uygulama, 12(6), 1273-1289.

Dono, J., Webb, J., \& Richardson, B. (2009). The relationship between environmental activism, proenvironmental bahaviour and social identity. Journal Of Environmental Psychology (Article İn Press): 19.

Ek, H. N. Kılıç, N., Öğdüm, P., Düzgün, G., \& Şeker, S. (2009). Adnan menderes üniversitesinin farklı akademik alanlarında öğrenim gören ilk ve son sınıf öğrencilerinin çevre sorunlarına yönelik tutumları ve duyarlılıkları. Kastamonu Eğitim Dergisi, 17:(1),125-136 
Erten, S. (2004). Çevre eğitimi ve çevre bilinci nedir, çevre eğitimi nasıl olmalıdır? Çevre ve İnsan Dergisi, Çevre ve Orman Bakanlığı Yayın Organı, 65/66: 2006/25.

Fraenkel, Wallen \& Hyun (2012). How to design and evaluate research in education. New York: McGraw-Hill.

Gökçe, N., Kaya, E.,Aktay, S. \& Özden, M. (2007). İlköğretim öğrencilerinin çevreye yönelik tutumları. İlköğretim Online, 6(3),452-468.

Hoody, L. (1995). The educational efficacy of environmental education (interim report). San Diego, CA: State Education and Environment Roundtable.

Horton, D. (2003). Green distinctions: The performance of identity among environmental activists. The The Sociological Review, 51(2),63-77.

IEEP (1994). An environmental education curriculum for pre-service education of secondary level teachers. UNESCO-UNEP-IEEP: Environmental. Education Series (43).

Kahyaoğlu, M. (2014). The research of the relationship between environmentally aware prospective teachers' qualities and self efficacy beliefs towards environmental education. Procedia-Social and Behavioral Sciences, 116,4493-4497.

Kahyaoğlu, M. Daban, Ş. \& Yangın, Y. (2008). İlköğretim öğretmen adaylarının çevreye yönelik tutumları. D.Ü. Ziya Gökalp Eğitim Fakültesi Dergisi, 11,42-52.

Kaya, İ. \& Gündoğdu, Y. (2007). Coğrafya öğretmenlerinin çevre bilincini oluşturma ve geliştirmedeki rolü: Diyarbakır örneği. Doğu Coğrafya Dergisi, 18,187-204

Keleş, Ö., Uzun, N. \& Varnacı-Uzun, F. (2010). Öğretmen adaylarının çevre bilinci, çevresel tutum, düşünce ve davranışlarının doğa eğitimi projesine bağlı değişimi ve kalıcılığının değerlendirilmesi, Elektronik Sosyal Bilimler Dergisi, 9(32),384-401

Köse, E. Ö.,\& Gül, Ş. (2014). Öğretmen adayları için çevre sorumluluğuna bağlı tüketim bilinci ölçeğinin geliştirilmesi. Journal Of Educational Sciences \& Practices, 13(26),257-277

Maskan, A. K., Efe, R., Gönen, S., \& Baran, M. (2006). Farklı branşlardaki öğretmen adaylarının çevre sorunlarının nedenleri, eğitimi ve çözümlerine ilişkin görüşlerinin değerlendirilmesi üzerine bir araştırma. Çukurova Üniversitesi Eğitim Fakültesi Dergisi. 3(32),1-12.

MEB (2015). Ortaöğretim coğrafya dersi taslak öğretim programı. Millî Eğitim Bakanlığı Talim Ve Terbiye Kurulu Başkanlığı, Ankara

Meydan, A. \& Doğu, S. (2008). İlköğretim ikinci kademe öğrencilerinin çevre sorunları hakkındaki görüşlerinin bazı değişkenlere göre değerlendirilmesi, Selçuk Üniversitesi Ahmet Keleşoğlu Eğitim Fakültesi Dergisi, 26, 267-277.

Ozden, M. (2008). Environmental awareness and attitudes of student teachers: An empirical research. International Research İn Geographical And Environmental Education, 17(1),40-55.

Özgen, N. \& Kahyaoğlu, M. (2012). Öğretmen adaylarının çevre sorunlarına yönelik tutumlarının çeşitli değişkenler açısından incelenmesi. Kuramsal Eğitimbilim Dergisi, 5(2), 171-185

Öztürk, E. (2013). Uluslararası bir çevre eğitimi projesinin fen ve teknoloji öğretmen adaylarının çevre bilincine etkisi. Yayınlanmamış Doktora Tezi. Hacettepe Üniversitesi Eğitim Bilimleri Enstitüsü İlköğretim Anabilim Dalı. Ankara

Roberts, J. A.,\& Bacon, D. R. (1997). Exploring the subtlerelationships between environmental concern and ecologically conscious consumer behavior. Journal Of Business Research, 40(1),79-89.

Sağır, S., Aslan O. \& Cansaran, A. (2008). İlköğretim öğrencilerinin çevre bilgisi ve çevre tutumlarının farklı değişkenler açısından incelenmesi. İlköğretim Online E-Dergi, 7(2), 496-511.

Seçkin, F., Yalvaç, G., \& Çetin, T. (2010). İlköğretim 8. sınıf öğrencilerinin karikatürler aracıllğıyla çevre sorunlarına ilişkin algıları, International Conference on New Trends in Education and Their Implications, 11(13), 391-398.

Soontonsmai, V. (2001). Predicting intention and behavior to purchase environmentally sound or green products among Thai consumers: An application of the Theory of Reasoned Action, Unpublished Doctor of Philosophy, Nova Southeastern University. USA

Sülün, Y. \& Kozcu , N. ( 2005). İlköğretim 8. sınıf öğrencilerinin lise girişi sınavlarındaki çevre ve popülasyon konusuyla ilgili grafik sorularını algılama ve yorumlamalarındaki yanılgıları. Erzincan Eğitim Fakültesi Dergisi. 7 ( 1 ), 25-33

Straughan, R. D., \& Roberts, J. A. (1999). Environmental segmentation alternatives: a look at green consumer behavior in the new millennium. Journal of Consumer Marketing. 16(6), 558-575.

Şama, E. (2003). Öğretmen adaylarının çevre sorunlarına yönelik tutumları. Gazi Eğitim Fakültesi Dergisi, 23(2),99-110

Tabachnick, B. C., \& Fidell, L. S. (2007). Using multivariate statistics (5th ed.). Boston, MA: Pearson Education, Inc. USA

Tahiroglu, M., Yıldırım, T. \& T. Çetin, T. (2010). Değer eğitimi yöntemlerine uygun geliştirilen çevre eğitimi etkinliğinin, ilköğretim 7. Sınıf öğrencilerinin çevreye ilişkin tutumlarına etkisi. Selçuk Üniversitesi Ahmet Keleşoğlu Eğitim Fakültesi Dergisi Sayı 30,231-248 
Tahiroglu, M. \& T. Cetin, T. (2013). The effect of the activity based education on teaching the love of nature value in social studies course and the gain and the attitude levels of the students. International Journal of Academic Research Part B, 5(1), 226-236.

Timur, S. \& Yılmaz, M. (2011). Fen bilgisi öğretmen adaylarının çevre bilgi düzeylerinin belirlenmesi ve bazı değişkenlere göre incelenmesi, Gazi Üniversitesi Gazi Eğitim Dergisi, 31(1), 303-320.

Torlak, Ö. (2001). Pazarlama ahlakı, Beta Basım, 1. Baskı. İstanbul.

Tuncer, G., Tekkaya, C, Sungur, S., Cakiroglu, J., Ertepinar, H., \&Kaplowitz, M. (2009). Assessing pre-service teachers' environmental literacy in turkey as a mean to develop teacher education programs. International Journal of Educational Development, 29(4), 426-436.

Türküm, A.S, (1998). Çağdaş toplumda çevre sorunlari ve çevre bilinci. (Editör. G. Can) Çağdaş Yaşam Çağdaş İnsan. Eskişehir: Anadolu Üniversitesi Açık Öğretim Fakültesi İlköğretim Öğretmenliği Lisans Tamamlama Programı, 165-181.

Ünal, S. \& Dımışk1, E. (1999). UNESCO UNEP himayesinde çevre eğitiminin gelişimi ve türkiye'de ortaöğretim çevre eğitimi. Hacettepe Üniversitesi Eğitim Fakültesi Dergisi, 17,142-154.

Yaraş, E., Akın, E. \& Şakacı, B. A., (2011) Tüketicilerin çevre bilinci düzeylerini belirlemeye yönelik bir araştırma. Öneri Dergisi, 9(35), 117-126.

Yeniçeri, T. (2009). Tüketicilerin çevre bilinci ve çevreye duyarlı satın alma davranışlarına yönelik bir pilot araştırma. Sosyal Ve Ekonomik Araştırmalar Dergisi, 11(17), 311-326.

Yılmaz, Ö. \& Anderson, H.O. (2004). Views of elementary and middle school Turkish students toward environmental issues. International Journal of Science Education, 26, 1527-1546.

Yılmaz, V., Çelik, H. E. \& Yağızer, C. (2009). Çevresel duyarlılık ve çevresel davranışın ekolojik ürün satın alma davranışına etkilerinin yapısal eşitlik modeliyle araştırılması, Anadolu Üniversitesi Sosyal Bilimler Dergisi 9(2), 1-14.

Yücel, M., Uslu, C., Altunkasa, F., Güçray, S.S., Say, N.P., (2008). Adana'da halkın çevre duyarlılığının saptanması ve bu duyarlılığı arttırabilecek önlemlerin geliştirilmesi. Adana Kent Sorunları Sempozyumu, 9- 10 Mayıs, , 363-382. Adana.

\section{Author Information}

Yurdal Dikmenli

Ahi Evran University

Faculty of Education

Turkey

Contact e-mail: dikmenliy@hotmail.com 